\title{
FAKTOR-FAKTOR YANG MEMPENGARUHI PENGAMBILAN KEPUTUSAN BERMIGRASI MASYARAKAT MADURA KE KELURAHAN BURING KECAMATAN KEDUNG KANDANG KOTA MALANG TAHUN 2017
}

\author{
${ }^{1)}$ Ratri Ning Tyas; ${ }^{2)}$ Triwahyudianto; ${ }^{3)}$ Dwi Fauzia Putra \\ 1) 2) 3) Universitas Kanjuruhan Malang \\ Email: ${ }^{1)}$ ratriningtyas25@ gmail.com; ${ }^{2)}$ u.diant@yahoo.com; \\ 3)dwifauziaputra@unikama.ac.id
}

\begin{abstract}
Abstrak
Tujuan penelitian ini adalah untuk mengetahui lebih dalam alasan migran Madura bermigrasi ke Kelurahan Buring Kota Malang dengan melihat dari faktor pendorong dan penarik.Teknik pengumpulan data menggunakan observasi, wawancara dan data dokumentasi. Analisis data menggunakan model analisis kualitatif untuk keabsahan temuan menggunakan triangulasi. Temuan penelitian bahwa sejarah migran bisa sampai di Buring karena di Madura lahannya panas dan kurang subur sehingga. Ada 6 faktor pendorong yang menyebabkan Madura bermigrasi ke Kota Malang yaitu: kendala pengolahan lahan pertanian, kondisi ekonomi, pendidikan rendah, sarana dan prasarana pendidikan yang kurang memadai, tidak cocok dengan budaya daerah asal, lapangan pekerjaan terbatas. Terdapat 4 faktor penarik dari daerah tujuan yang menarik masyarakat Madura untuk melakukan migrasi yaitu: mendapat pekerjaan yang lebih baik, sarana kenyamanan, kesempatan membuka lapangan pekerjaan, aktivitas kota besar. Dalam pengambilan keputusan yang dilakukan migran ada 3 yaitu keputusan diri sendiri, keputusan orang lain dan keputusan keluarga inti.
\end{abstract}

Kata Kunci: Faktor pendorong dan penarik, keputusan migrasi, Keluruhan Buring.

\section{PENDAHULUAN}

Arus migrasi dari desa ke kota seringkali mengakibatkan dampak negatif di kota besar. Akibatnya yaitu lingkungan di Kota kumuh, daerah pemukiman di sempadan sungai.Di Kota tindakan kriminalitas marak akibat dari pengangguran. Dikota banyak pengemis dan pengamen di jalan.Di daerah tujuan kepadatan berasal karena semakin banyak penduduk yang mencari pekerjaan.Permintaan terhadap kesempatan kerja, fasilitas infrastruktur dan pelayanan kota seperti : komunikasi, sekolah, rumah sakit,air, penerangan dan listrik cenderung meningkat.

Untuk mengatasipermasalahan tersebut telah diadakan usaha untuk membatasi arus migrasimasuk ke kota dan menciptakan lapangan kerja di daerah asal. Namun hal iniseringkali tidak berhasil karena kurangnya pemahaman tentang alasan orangberpindah, ada orang yang berpindah ke kota sebagai tahap akhir setelahberpindah beberapa kali ke kota lain dan ada yang berpindah hanya untuk sementara waktu.

Migrasi didefinisikan sebagai perpindahan penduduk dari suatu tempat ke tempat lain yang melampaui batas politik atau negara ataupun batas administrasi atau batas bagian suatu negara. Migrasi yang melampaui batas negara disebut dengan migrasi internasional sedangkan migrasi internal merupakan perpindahan penduduk yang terjadi dalam batas wilayah suatu negara, baik antar daerah ataupun antar propinsi. Beberapa studi migrasi menyimpulkan bahwa migrasi terjadi 
disebabkan oleh alasan ekonomi Todaro dalam Puspitasari (2010).

Terdapat sejumlah faktor rintangan salah satunya adalah mengenai jarak, walaupun rintangan "jarak" selalu ada namun tidak selalu menjadi faktor penghalang. Faktor rintangan mempunyai pengaruh yang berbedabeda pada orang-orang yang akan pindah. Faktor individu merupakan faktor yang sangat menentukan dalam pengambilan keputusan untuk migrasi. Semakin maju kondisi sosial ekonomi suatu daerah akan menciptakan faktor penarik, seperti perkembangan industri, perdagangan, pendidikan, perumahan, dan transportasi. Disisi lain, daerah mempunyai faktor pendorong (push factor) yang menyebabkan sejumlah penduduk migrasi ke luar daerahnya, antara lain kesempatan kerja yang terbatas jumlah dan jenisnya, sarana dan prasarana pendidikan yang kurang memadai, fasilitas perumahan dan kondisi lingkungan yang kurang baik.(Mantradalam Andias,2014)

Penelitian Rizal (2006) dengan judul "Keputusan Migrasi Sirkuler Pekerja Sektor Formal di Kota Medan". Penelitian ini menganalisis tentang faktor-faktor yang mempengaruhi mirgasi sirkuler di Kota Medan.Data yang digunakan adalah data primer yang bersumber dari para responden yang diperoleh melalui kuesioner yang telah dipersiapkan.Metode analisis yang digunakan adalah analisis regresi berganda, karenaterdapat lebih dari satu variabel independen, dan analisis model logit.

Variebel yang digunakan berupa variabel dependen, yaitu migrasi atau tidak migrasi dan variabel independen terdiri dari jenis pekerjaan, tingkat pendidikan, daya tarik kota, daya dorong desa dan status kepemilikan tanah, dengan alpha 5\%. Berdasarkan hasil pengujian, semua variabel independen berpengaruh $12,3 \%$ secara signifikan terhadap migrasi sirkuler di Kota Medan. Secara pastial, hanya tingkat pendidikan yang berpengaruh terhadap migrasi sirkuler di Kota Medan.

Penelitian Utami (2016) dengan judul Faktor-faktor yang mempengaruhi pengambilan keputusan bermigrasi di Desa Tumpak Pelem kecamatan Sawo Kabupaten Ponorogo. Penelitian oleh Utami relevan dengan penelitian ini, karena sama -sama membahas mengenai migrasi yang difokuskan pada penjelasan faktor yang mempengaruhi pengambilan keputusan bermigrasi.

Studi migrasi ini penting dilakukan karena dengan mengetahui faktor pendorong dan proses pengambilan keputusan masyarakat migrant Madura di Kelurahan Buring Kecamatan Kedung Kandang Kota Malang dapat digunakan untuk mengatasi permasalahan - permasalahan yang timbul di daerah asal maupun tujuan. Pemerintah daerah dapat menyediakan hal -hal yang tidak tersedia di daerah asal sehingga meminimalisir migrasi dan dampaknya.

\section{METODE PENELITIAN}

Penelitian ini menggunakan metode kualitatif. Teknik pengumpulan data menggunakan metode observasi, wawancara dan dokumentasi. Analsis data dalam penelitian ini menggunakan model kualiatif. Keabsahan data menggunakann triangulasi. Informan ada dua yaitu informan kunci dan informan pendukung. Informan pendukung ada dua yaitu Pak Lurah Agus dan bapak Choiril Anwar 
sekretaris yang ada di kelurahan sedangkan informan kunci ada 14 orang. Abdul Hasan bekerja di rumah yaitu penyewaan Alat, Beti Penjual Baju, Giman pekerjaanya bertani, Abdullah pekerjaannnya petani dan mengajar ngaji, Abdul Gofur di rumahnya membuka toko material, Susy bekerja di pasar besar sebagai penjaga toko, hotimah sebagai ibu rumah tangga, Sugik pejual buah, Samsul sebagai tukang bangunan, Abdul Rozak penjual ayam di pasar Gadang, khodir penjual buahh. Suminah penjual jamu, Rupiati pedagang di pasar, Misdi buruh tani.

\section{HASIL DAN PEMBAHASAN}

\section{Faktor Pendorong Kendala pengolahan lahan pertanian}

Masyarakat di Madura banyak yang meninggalkan daerahnya karena kondisi lahan yang kurang subur untuk ditanami jadi masyarakat yang ada di Madura banyak yang keluar dari daerahnya untuk merantau ke daerah luar. Daerah yang dituju kebanyakan daerah yang dekat dengan Madura. Salah satunya yaitu Kota Malang, Kota Malang ini di pilih oleh migrant Madura karena dianggap lebih dekat dan strategis dengan daerah asal.

"Gini-ini dek saya kasih tau ceritanya Masyarakat madura banyak yang pindah ke kota Malang. Awalnya itu dulunya di Madura musim kemarau panas, lahannya tidak bisa ditanami apa-apa tandus. Orang madura bingung carik cara ya.. Orang Madura lari ke Kota Malang karena Malang lebih dekat dari Madura jaraknya tidak terlalu jauh mangkanya orang madura milih di kota Malang. Tapi Malang bagian timur, utara dan selatan yang dipilih Madura karena daerahnya dingin dan masih asri" (Abdullah, 2017).
Menurut Lee (1976) adanya kondisi lingkungan yang kurang baik akan menyebabkan sejumlah penduduk melakukan migrasi keluar dari daerahnya untuk memperoleh lingkungan yang dirasa baik. Jika lingkungan itu baik maka seseorang akan melakukan migrasi bahkan orang akan tetap tinggal di daerah tujuan itu. Mereka akan merasa lingkungan menjadi sahabat yang baik untuk mempertahankan diri individu.

Jadi lingkungan itu akan membawa individu dalam mempertahankan hidup jika lingkunngan dirasa baik. Kondisi lingkungann yang kurang baik membuat penduduk akan melakukann migrasi ke luar dari daerah asal mereka. Mereka akann mencari lingkunngan yang cocok untuk dirinya. Kondisi lingkungan yang kurang baik membuat penduduk tidak merasa nyaman untuk tetap tinggal di daerah asal.

\section{Kondisi Ekonomi}

Ekonomi di Madura itu rendah karena disana perputaran uang itu kecil, tidak sebesar di Malang. Di Madura penduduknya banyak yang melakukan migrasi ke luar dari daerah asalnya. Mereka lebih yakin melakukan migrasi ke luar dari daerah asalnya ke daerah tujuan untuk mengubah hidupnya. Ekonomi yang sulit di Madura membuat migran Madura untuk datang ke Buring. Mereka akan cari pengalaman seperti yang telah disampaikan oleh ibu Sum beliau tidak mau nikah muda tetapi beliau akan bermigrasi ke luar daerah untuk mengubah hidupnya. Berikut penjelasan yang disampaikan oleh informan:

\footnotetext{
"Ekonomi keluarga kurang, keadaanya ya pas-pas tapi tidak lebih. Saya tidak mau nikah muda takut tidak bisa
} 
bahagiaan anak.Tetapi saya ingin merantau cari pengalaman ke Malang". (Suminah, 2017)

Artinya:

"Ekonomi keluarga saya kurang, keadaannya cukup tetapi tidak lebih. Saya tidak mau menikah muda karena takut tidak bisa membahagiakan anak saya. Saya mempunyai keinginan untuk merantau ke Malang”. (Suminah, 2017).

Teori Ravenstain (1889) mengatakan bahwa motif ekonomi merupakan pendorong utama seseorangmelakukan migrasi, semakin tinggi pendapatan seseorang, semakin tinggi frekuensi mobilitas orang tersebut. Dimana ada peningkatan pendapatan perkapita akan mengakibatkan pertumbuhan ekonomi. Hal ini sesuai dengan teori Todaro (1969) yang mengatakan bahwa terdapat perbedaan tingkat upah antara desa dan kota. Para migran memprediksikan bahwa pendapatan yang diharapkan di kota akan lebih banyak.

Sama halnya dengan penelitian yang dilakukan oleh Utami (2005) yang mendorong untuk melakukan migrasi ke luar negeri untuk memperoleh penghasilan yang lebih tinggi dan meningkatkan kemampuan ekonomi. Ekonomi yang lemah di Madura membuat masyarakatnya meninggakan daerah asalnya, disana daerahnya sepi tidak seramai yang ada di Kota Malang. Masyarakat Madura tidak dapat mencukupi kebutuhan sehari-hari mereka merasa di daerah asal tidak memperoleh pendapatan dan kemungkinan memperoleh pendapatan di daerah tujuan yaitu di Kota Malang. Ini yang menyebabkan masyarakat Madura bermigrasi ke Kota Malang.

Dengan meninggalkan daerahnya menuju daerah tujuan ini adalah tujuan dari masyarakat migran untuk memperbaiki hidupnya. Ibu sum ini orang tuanya bekerja sebagai pembuat jamu, sampai sekarang ibu sum meneruskan usaha yang dilakukan oleh ibunya. Ekonomi yang lemah di Madura membuat masyarakatnya meninggakan daerah asalnya, disana daerahnya sepi tidak seramai yang ada di Kota Malang. Masyarakat Madura tidak dapat mencukupi kebutuhan sehari-hari mereka merasa di daerah asal tidak memperoleh pendapatan dan kemungkinan memperoleh pendapatan di daerah tujuan yaitu di Kota Malang. Ini yang menyebabkan masyarakat Madura bermigrasi ke Kota Malang.

\section{Pendidikan yang Rendah}

Masyarakat migran Madura melakukan migrasi ke Buring salah satunya adalah pendidikan yang rendah. Pendidikan di Madura dulunya hanya sampai tamatan dari SD. Dahulu sekolah SD itu sudah dianggap lebih baik. Setelah lulus SD anak perempuan sudah disuruh menikah. Anak laki-laki bekerja sebagai buruh asalkan semua itu bisa mendapatkan uang.

Menurut Lee (1987) bahwa pendidikan yang kurang memadai atau rendah akan mendorong seseorang untuk melakukan migrasi. Karena dengan bermigrasi mereka akan memperoleh pendidikan yang lebih baik. Jika pendidikan rendah akan mempengaruhi kualitas keluaran pendidikan.Hasil penelitian terdahulu oleh Bagus, (2006) yang berjudul Migrasi Sirkuler Tenaga Kerja Wanita Ke Luar Negeri : Studi Kasus Tentang Proses Pengambilan Keputusan Bermigrasi Oleh wanita Pedesaan di Jawa menggunakan variabel tingkat pendidikan. Semakin tinggi tingkat pendidikan maka tenaga kerja akan mencari pekerjaan yang lebih baik atau memilih bekerja pada sektor formal. Penelitian yang dilakukan oleh Ida 
Bagus ini berbeda dengan penelitian yang sedang dilakukan

Waktu itu keadaan di Madura lapangan kerja sempit, belum ada usaha-usaha yang besar. Sehingga banyak migran yang tertarik untuk melakukan migrasi keluar dari daerahnya. Migran di daerah asal sulit menemukan lapangan kerja. Hal ini dijelaskan oleh informan pada saat melakukan wawancara.

\footnotetext{
"Hal yang pokok ya gitu lapangan kerja sulit di Madura bingung mau kemana dulu itu saya dulu SMP gak lulus. Saya dulu ya nakal kalau ukuran anak sekarang. Soalnya ya gitu, malas sekolah" (Khodir,2017).

Artinya:

"Hal yang utama adalah lapangan pekerjaan sulit di Madura, bingung mau pergi kemana dahulu saya tidak lulus SMP. Saya dulu nakal kalau hitungan anak sekarang karena saya malas pergi sekolah" (Khodir,2017).
}

Pendidikan di Madura tidak dinomersatukan. Wajib belajar 12 tahun masih tidak diterapkan. Akibatya banyak masyarakat Madura yang sedikit mendapatkan bangku sekolah. Rata-rata masyarakat Madura tamatan Sekolah Dasar. Pendidikan yang rendah akan menyebabkan pengangguran dan lapangan kerja kurang.

\section{Sarana dan Prasarana Pendidikan Kurang Memadai}

Sarana dan prasarana yang ada di Madura masih belum memadai, Sekolah untuk jenjang SMP di Madura harus pergi ke Kota dahulu. Sekolah SD di daerah hanya satu yang negeri dan yang lainnya sekolah islam. Jarak antara sekolah dengan rumah membutuhkan waktu yang sangat lama. Ini yang membuat anak-anak di Madura tidak melanjutkan sekolah lagi dan tidak sampai selesai sekolahnya. Hal ini dijelaskan oleh informan yaitu:

\begin{abstract}
"Ya gak kayak sekarang, dulu sekolah papan aja, penggaris ya tidak ada. Kamar mandi ya tidak ada. Cumak hanya bangunan gituMau sekolah ya jauh daerahnya harus ke Kota dan nginap di Kota. Paleng di Madura tamatan SD sama SMP sudah bagus seumuranku dulu” (Khotimah, 2017).

Artinya:

"Ya tidak sama seperti sekarang ini alatalat sekolah lengkap...Kalau ingin sekolah jauh harus pergi ke Kota dan menginap. Tamatan SD dan SMP sudah bagus seumuran saya" (Khotimah, 2017).
\end{abstract}

Dalam teori Everett Lee (1987) fasilitas yang kurang mendukung membuat penduduk tidak nyaman didaerahnya.Mereka akan cenderung melakukan migrasi ke luar dari daerahnya.

Daerah sekolah yang jauh membuat siswa malas untuk datang bersekolah, mereka lebih memilih untuk bekerja daripada datang kesekolah. Jika tidak ada dorongan yang lebih dari orang tua, anak tersebut bisa putus sekolah. Biasanya anak perempuan yang putus sekolah atau yang tidak sekolah mereka cenderung disuruh menikah. Ada sistem perjodohan di Madura yang penting anak sudah menikah orang tua merasa lega dan tidak punya beban lagi. Karena jika anak perempuan sudah menikah itu tanggungjawab seorang laki-laki.

Jadi sarana dan prasarana pendidikan akan mempengaruhi proses belajar mengajar yang kondusif di dalam kelas. Jika sarana dan prasarana yang kurang memadai akan mematahkan semangat belajar siswa. Siswa akan datang kesekolah dengan terpaksa dan tidak ada daya tarik untuk mengembangkan bakatnya di sekolah. Mereka tidak mempunyai semangat untuk mengejar mimpinya di sekolah. 
Tidak Cocok dengan Budaya Daerah Asal

Sempitnya lapangan kerja membuat warga di Madura sulit untuk mendapatkan uang, karena rendahya pendidikan menjadikan penganggguran di Madura juga banyak disamping itu lapagan kerja di Madura juga sempit. Hal in dijelaskan oleh informan yaitu:

\footnotetext{
"Ya disana itu mau kerja apa juga bingung seusiaku, aku ya lulusan SD, takutnya ibu ini dulu disuruh nikah sama bapakku, kan orang tua disana ya gitu kalau punya anak gadis gak ngapangapa di rumah ya nikah aja, jadi ramerame sama teman di sebelah rumah pergi ke malang” (Sum,2017).

Artinya:

"Di Madura sana juga bingung mencari pekerjaan seusia saya dulu, saya hanya lulus SD, saya dulu takut kalau dijodohkan sama orang tua saya. Tradisi di Madura kalau mempunyai anak gadis sudah dijodohkan. Jadi saya dan temanteman di daerah saya pergi bermigrasi ke Malang” (Sum,2017).
}

Munir (1981) mengatakan bahwa seseorang melakukan migrasi karena tidak cocok lagi dengan adat budaya/kepercayaan di daerah asal. Masyarakat migran ada yang meninggalkan daerah asal karena tidak cocok dengan budaya setempat. Budaya yang ada di tempat mereka berasal akan mempengaruhi penduduk yang mendiami suatu daerah dimana mereka tinggal. Jika mereka tidak menyukai budaya asal mereka akan meninggalkan daerah tersebut dan berpindah ke daerah tujuan yang dianggap cocok dengan dirinya.

$\mathrm{Bu}$ Sum meninggalakan Madura saat usia remaja, beliau pergi ke Malang bersama denan teman-temanya yang berasal dari Madura. Bu Sum perg ke Malang ini untuk mencari pekerjaan,karena saat di Madura beliau tidak mempunyai pekerjaan. Sampai di Malang Bu Sum menemukan jodoh dan beliau menetap tingga di Buring.

\section{Lapangan pekerjaan terbatas}

Lapangan pekerjaan di Madura terbatas karena disana tidak ada pabrik-pabrik dan industri ini mengakibatkan banyak masyarakatnnya berpindah ke Malang. Masyarakat Madura Hal ini dijelaskan oleh informan :

\begin{abstract}
"Saya tidak kerja di Madura hanya membantu ibu jualan kan disana dulu tidak ada pabrik...Dulunya saya itu jual jamu sama orang tua di Madura. Tetapi saya ingin merantau cari pengalaman ke Malang. Karena di Madura itu susah dapat kerjaan iku. Saya kesini dulu ya sama teman-teman dari sana banyak, dulunya masih numpang di saudaranya teman saya. Dulu dicarikan kontrakan tapi kayak kos gitu” (Suminah, 2017).

Artinya:

"Saya tidak kerja di Madura hanya membantu ibu jualan kan disana dulu tidak ada pabri ...Dahulunya saya membantu orang tua menjual jamu di Madura, tetapi saya ingin merantau ke Malang. Karena di Madura itu susah dapat kerjaan iku Saya bermigrasi ke Malang bersama dengan teman-teman dari Madura. Pertama kali datang kesini saya menumpang di rumah saudara teman saya sambil mencari kontrakan" (Suminah, 2017).
\end{abstract}

Setelah Bu Sum lama di Malang, Bu Sum mencoba kerja - kerja ditoko sampai Bu Sum menikah di Malanng. Setelah menikah bu Sum membeli tanah dan membangun rumah di Buring. Ibu Sum meneruskan usaha orang tua nya. Di Madura orang tua Ibu Sum seorang penjual jamu. Sampai sekarang ini di Buring Ibu Sum berjualan jamu dengan keliling.

Teori migrasi Ravenstain (1880) menunjukkan bahwa faktor paling dominan yang mempengaruhi seseorang untuk bermigrasi adalah sulitnya 
memperoleh pekerjaan di daerah asal dan kemungkinan memperoleh pekerjaan dan pendapatan yang lebih baik di daerah tujuan. Daerah tujuan harus mempunyai nilai kefaedahan (place utility) lebih tinggi dibanding daerah asal.

Penelitian yang dilakukan oleh Sudibia (2005) Kecenderungan Pola Dan Dampak Migrasi Penduduk Di Provinsi BaliPeriode 1980-2005*. Selain untuk mendapatkan peluang kerja di daerah tujuan mereka beranggapan di daerah tujuan akan lebih maju dan bisa memperoleh pekerjaan yang diinginkan. Seseorang melakukan migrasi dengan tujuan untuk mendapat kesempatan kerja yang tidak mereka dapatkan di daerah asal mereka.

Jadi lapangan pekerjaan yang luas dan banyak akan mendorong seseorang untuk berpindah dari daerah asal ke daerah tujuan hal ini dilakukan untuk memperbaiki ekonominya.

\section{Faktor Penarik Masyarakat Madura Bermigrasi ke Kelurahan Buring Kesempatan Mendapatkan Pekerjaan yang Lebih Baik}

Migran dari Madura berpindah ke daerah tujuan itu karena faktor pekerjaan karena orang yang asli Madura sudah banyak yang meninggalkan Madura akibatnya di Madura usia produktif menjadi sedikit. Jadi orang Madura lebih percaya ke daerah tujuan dari pada daerah aslinya. Seperti pak Sardi beliau datang ke Malang ini kedua kalinya. Pertama beliau sudah sampai di Malang lalu beliau kembali lagi ke pulang di Madura setelah kembali lagi ke Madura beliau tidak mendapatkan pekerjaan. Beliau ingin bekerja lagi dan kembali ke Malang. Hal ini dijelaskan oleh informan yaitu:

"Golek duwe abot ing kono Kasile sitik,
jaman semono golek 20 ewu iku pirang
dino. Ing daerah bapak ora ole duwek
semono. Dadine yo balek ing Malang
meneh. Ing malang jinise penggawenan
a ekeh lek digolek i.akeh wong e yo an"
(Sardi, 2017).
Artinya:
"Mencari uang itu susah dan hasilnya
sedikit,pada saat itu mencari uang Rp
20.000,00 itu butuh beberapa hari. Di
daerah bapak sulit mencari uang jadinya
saya kembali lagi ke Malang. Di Malang
jenis pekerjaan banyak, orangnya juga
banyak."(Sardi, 2017).

Beliau lebih percaya di Malang sampai beliau ingin kembali ke Malang lagi, karena di Madura sulit memperoleh kesempatan kerja. Pada waktu itu menurut pak Sardi jenis pekerjaan sudah banyak. Berbeda dengan ibu Rupiati beliau baru datang pertama kali ke Malang beliau ingin mencoba hal baru. Dalam teori Everett (1976) menyatakan bahwa adanya faktor penarik dari daerah tujuan sehingga meninggalkan daerah asal, mengakibatkan menyempitnya lapangan pekerjaan. Sehingga penduduk merasa mempunyai kesempatan untuk memasuki lapangan pekerjaan ditempat tujuan migrasi yang dapat memberikan daya tarik untuk paramigran yang sebelumnya tidak/belum bekerja di daerah asal.

\section{Kenyamanan lingkungan}

Alasan migrant Madura berpindah ke Buring sini karena tempatnya nyaman. Selain itu Burisng di dikenal dengan daerahnya yang dingin dan asri sehingga masyarakat migrant Madura bisa nyaman berada di Buring. Pengembangan lahan disini juga pesat sampai saat ini daerah di Buring banyak diminati masyarakat Madura karena 
semakin hari daerah disini penduduk juga bertambah.

Keadaan lingkungan dan keadaan hidup yang menyenangkan membuat migran tertarik untuk melakukan migrasi Munir (1981). Menurut ibu Beti migrant yang berasal dari Madura Pamekasan "Saya beli rumah disini mbak, karena tempatnya enak dan daerahnya dekat dengan Kota" (Bety, 2017).

Penelitian Utami (2005) terdapat lapangan pekerjaan yang sesuai di daerah tujuan yang dapat menarik migran ke luar dari Desa Jangkaran, Kecamatan Temon Kabupaten Kulon Progo ke luar negeri. Pada penelitian utami sebagaian besar penduduk perempuan melakukan migrasi ke luar negeri. Kaena menjadi seorang Tenaga Kerja Wanita di luar negeri akan mendapat gaji yang lebih besar daripada di dalam negeri.

Jika daerah tersebut dianggap nyaman maka orang yang merasakan akan tertarik untuk melakukan migrasi. Karena jika tidak nyaman seseorang tidak akan betah atau tinggal didaerah tersebut.

\section{Kesempatan Membuka Lapangan Pekerjaan}

Lapangan kerja di Madura sedikit, Malang sebagai faktor penarik migran dari Madura. Seperti Ibu Beti di daerah asal beliau tidak bisa membuka lapangan kerja sendiri tetapi saat di Malang beliau bisa mencukupi ekonomi keluarga bersama suami membuka usaha sendiri. Di daerah tujuan Munir (1981) mengatakan adanya rasa superior di tempat yang baru atau kesempatan untuk memasuki lapangan pekerjaan yang cocok. Lapangan pekerjaan yang mereka suka akan membuat mereka nyaman untuk menjalani kegiatan sehari-hari. Jika pekerjaan itu sesuai dengan yang diharapkan pekerjaan itu akan terusmenerus. Adanya kesukaan dalam pekerjaan tidak akan bosan saat melakukan pekerjaan meskipun dalam bekerja. Di daerah yang baru mereka akan mempunyai semangat kerja yang tinggi.

Hal ini dijelaskan oleh informan:

"Disini awal saya berumah tangga dan
merasakan hidup sendiri tanpa bantuan
orang tua. Saya disini dapat kerja
sampai saat ini saya bisa mempunyai
rumah dan membuka usaha
sendiri"(Bety, 2017).
Artinya:
"Disini awal saya membangun rumah
tangga dan merasakan hidup mandiri
tanpa bantuan dari orang tua. Saya
disini bisa mempunyai pekerjaan, rumah
dan membuka usaha” (Bety, 2017).

Di daerah asalnya $\mathrm{Bu}$ Bety tidak bisa membuka usaha kaena minat untuk membeli di Madura itu sedikit. Bu Beti dan suami membuka usaha jual baju, kerudung, dan pakaian perempuan.

Penelitian Puspitasari (2010) yang berjudul Analisis Faktor - Faktor Yang Mempengaruhi Minat Migrasi Sirkuler Ke Kabupaten Semarang bahwa adanya kesempatan membuka lapangan pekerjaan yang baik akan menarik penduduk untuk melakukan migrasi.Kabupaten Semarang ini mempunyai jenis lapangan kerja yang banyak mereka juga bisa membuka lapangan pekerjaandi Kabupaten Semarang. Karena Semarng menjadi pusat kerajinan yang akan di kirim ke Jogja, Solo dan mancanegara. Kerajinan dan oleh-oleh ini membutuhkan tenaga kerja yang banyak. Oleh sebab itu banyak masyarakat yang melakukan migrasi ke Kabupaten Semarang. 
Jadi daerah tujuan bisa menarik masyarakat untuk melakukan mendapatkan pekerjaan yang lebih baik. Temuan yang dilakukan Utami ini mempunyai kesamaan dnegan temuan penelitian. Jika temuan yang dilakukan oeh Utami adalah migrasi perempuan yang menjadi tenaga kerja Indonesia. Jika temuan peneliti ini masyarakat Madura ingin mendapatkan pekerjaan yang lebih baik di Kota Malang. Seseorang akan meninggalkan daerah asal untuk mendapatkn pekerjaan yang lebih baik.

\section{Aktivitas Kota Besar}

Karena di Malang penduduknya banyak, lapangan kerja juga bervariasi banyak migran yang tertarik untuk berpindah ke daerah tujuan. Kota besar bisa menarik migran untuk datang ke Kota. Kota memiliki peranan yang penting untuk menarik migran yang datang ke daerah tersebut. Kota berperan penting untuk seseorang yang ingin datang ke wilayah yang baru. Akvitas Kota yang ramai sehingga orang akan tertarik untuk datang dan melakukan migrasi. Migrasi ke Kota dengan tujuan akan mendapatkan sesuatu disana. Penduduk yang melakukan migrasi ke Kota mereka akan memilih jenis pekerjaan yang dirasa sesuai dengan dirinya.

\footnotetext{
"Ya gak bisa kayaknya mbak, saya disana tinggal di desa. Kalau disini pasar induk tempat orang setiap harine pasti enek ae seng tuku, titik akeh e wong mampir. Apa meneh dina-dina wong duwe gawe rame, Pasar Gadang iki pasar induk panggnane owong kulakan mulai totok dinoyo sampai pucung dek kene kulakne" (Abdul Rozak, 2017).

Artinya :

"Ya tidak bisa sepertinya mbak saya disana tinggal didesa. Berbeda kalau disini pasar induk setiap hari pasti ada pembeli yang datang kesini. Apalagi hari-hari orang punya hajat. Pasar
}

Gadang ini tempat orang mengambil barang dari Dinoyo sampai Pucung”.

Pekerjaan di desa Madura sedikit oleh karena itu mereka berpindah ke kota. Mereka mencari tempat yang ramai, tempatt yang serng dkunjungi oleh orang. Mereka lebh suka berdagang di pasar, karena di pasar tempat rang bertransaksi jual beli. Mereka lebih suka merantau ke daerah lain,alasan utama mereka meninggalan daerahnya karena disana sepi.

Muhammad Rizal (2006) dengan judul "Keputusan Migrasi Sirkuler Pekerja Sektor Formal di Kota Medan". Penelitian ini menganalisistentang faktor-faktor yang mempengaruhi mirgasi sirkuler di Kota Medan. Karena di Medan menjadi pusat Kota yang membuat masyarakat yang ada disekitar sana tertarik apalagi dalam sektor formalnya. Dalam penelitian Rizal daya tarik kota sangat mempengaruhi migran untuk datang ke Kota. Di kota Medan pendidikan adalah yang paling utama, jadi tenaga pendidik yang lebih banyak di Kota Medan.

Pasar induk di Gadang ini pasar yang setiap harinya dikunjungi orang mulai dari Batu sampai Pucung. Pasar Gadang mendapat pasokan sayuran dari Batu dan daerah Tengger, tetapi jika ikan segar mereka mendapatka dari arah Malang selatan yaitu daerah Jalasutra dan Sendang Biru. Jika arah utara mendapat ikan dari daerah Lamongan, Pasar Gadang juga menerima ikan asin dari Madura.Aktivitas yang ada di Kota Malang yang padat membuat migran tertarik untuk berpindah ke Kota Malang. Di daerah asal mereka tidak seramai seperti yang ada di Malang. Aktivits yang ramai di Kota Malang membuat masyarakat Madura enggan untuk melakukan migrasi. Karena jika di Kota besar aktivitas selalu ramai 
maka lapangan kerja juga bervariasi ini alasan migran yang berasal dari Madura untuk bermigrasi ke Kota.

\section{Proses Pengambilan Keputusan Masyarakat Migran Madura Ke Kelurahan Buring}

Pengambilan keputusan dalam bermigrasi didasarkan ada tiga yaitu dari diri sendiri, orang lain dan keluarga inti.

\section{Orang lain}

Kebanyakan masyarakat migrant Madura didasarkan karena banyak teman atau rekan yang berhasil merantau sehingga banyak yang ingin memutuskan untuk meninggalkan daerah asalnya dan memutuskan merantau karena tertarik dengan keberhasilan orang lain. Teori Norris (1972) yang menyatakan informasi dari saudara yang menyatakan berita dari orang lain itu penting untuk diperhatikan. Hal ini sama dengan penelitian yang sedang dilakukan bahwa masyarakat migran Madura sebelum memutuskan untuk mengambil keputusan mereka juga melihat orang Madura yang lebih dahulu sampai di Malang. Setelah sampai di Malang migran yang berasal dari Madura sebelum mereka mendapat tempat mereka akan menumpang di rumah migran yang lebih dahulu sampai. Mereka akan menumpang sampai mereka mendapat rumah di Malang. Mereka akan memberi makan kepada migran yang baru datang. Orang madura sangat empati dengan migran yang baru datang karena mereka juga merasakan apa yang dirasakan migran yang baru sampai bermigrasi.Hal ini dijelaskan oleh informan dengan penjelasan:

Disini awal saya berumah tangga dan merasakan hidup sendiri tanpa bantuan orang tua. Pertama saya ya takut tapi lihat orang-orang Madura perantauan yang pindah ke Malang kok banyak. Jadi saya putuskan pindah.Saya disini dapat kerja sampai saat ini saya bisa mempunyai rumah dan membuka usaha sendiri. (Bety,2017)

Migrasi Madura Ke Buring ini sebagaian besar banyak yang berdagang membuka usaha sendiri. Seperti Bu Bety yang berjualan baju. $\mathrm{Bu}$ Bety awal pertama kali ke Malang bersama dengan suaminya. Beliau mengambil keputusan untuk berpindah ke Malang karena jika berdagangn di madura tidak seramai yang ada di Malang. Orang lain juga mempengaruhi dalam pengambilan keputusan, masyarakat migran akan tertarik jika sebelum mereka meninggalkan daerah mereka,mereka akan melihat orang yang telah bermigrasi terlebih dahulu. Jika mereka melihat ada perubahan di daerah tujuan maka seseorang akan melakukan migrasi. Orang yang dahulunya dekat dengan mereka kemudian mereka melakukan migrasi dan sukses di daerah migrasi maka seseorang migran akan tertarik melakukanya. Mereka mempunyai mimpi bahwa mereka akan sukses juga.

Dalam penelitian Sudibia (2005) yang berjudul Kecenderungan Pola Dan Dampak Migrasi Penduduk Di Provinsi Bali Periode 1980-2005. Kehadiran migran di Provinsi Bali sangat ditentukan oleh migran terdahulu karena mereka itulah yang memberikan informasi tentang kondisi ekonomi atau kemajuan yang ada di Bali. Di samping itu, migran terdahulu sering menjadi tempat persinggahan pertama, sebelum para migran baru ini mendapatkan tempat tinggal. Bahkan kadang-kadang migran terdahulu dengan suka rela memberikan tempat tinggal dan makan 
secara gratis sebelum migran baru memperoleh pekerjaan.

\section{Diri sendiri}

Bapak Giman mengambil keputusan sendiri beliau bermigrasi ke Malang untuk mencari pekerjaan.

Dahulunya beliau di Madura tidak mempunyai pekerjaan lalu beliau datang ke Malang untuk mencari pekerjaan. Hal ini dijelaskan oleh informan yaitu:

"Awale ya mutusne dewe aku iki yen
aren ing Malang Kerjaan iku mau nak
yen ing Sumenep angel megawe susah
lemah e atos ora kena ditanduri apa
maneh cedek laut. Megawe ne gawe
uyah petis, tapi gak duwe bondo ya gak
iso nglakone isone buruh. Oleh titik.
Dadi tukang ya sitik biyen wong gwe
omah" (Giman, 2017).
Artinya:
"Awalnya saya memutuskan sendiri..
Pekerjaan di Sumenep itu sulit karena
tanahya tandus dan tidak bisa ditanami,
apalagi yang dekat dengan laut.
Pekerjaannya membuat garam tetapi
kalau tidak mempunyai modal ya tidak
bisa membuka lapangan kerja. Jadi
tukang membuat rumah juga
sedikit"(Giman, 2017).

Bapak Giman memutuskan ke Malang karena disana tidak ada pekerjaan jadi pak Giman ingin mengubah dirinya. Keputusan yang diambil diri sendiri dalam pengambilan keputusan untuk bermigrasi, masyarakat Madura mengambil keputusan untuk keluar dari daerah asalnya agar mereka bisa mengubah hidupnya ke daerah yang dituju.

Keputusan yang diambil diri sendiri dalam pengambilan keputusan untuk bermigrasi, masyarakat Madura mengambil keputusan untuk keluar dari daerah asalnya agar mereka bisa mengubah hidupnya ke daerah yang dituju. Mereka berharap jika mereka meninggalkan daerah mereka harus maju. Keputusan diri sendiri yang diambil mereka juga bertanggungjawab kepada dirinya bahwa mereka mampu mengubah diriya menjadi lebih baik. Keputusan yang diambil oleh masyarakat migran yaitu ingin memperbaiki status dirinya, mereka percaya di daerah tujuan akan berkembang daripada didaerah asal mereka.

Menurut pendapat Lee (1976) faktor individu merupakan faktor yang sangat menentukan dalam pengambilan keputusan untuk migrasi.Melakukan migrasi adalah pilihan yang diambil individu untuk mengubah mobilitas dirinya.

Penelitian yang dilaukan oleh Listyarini (2010) yang berjudul Faktor-Faktor Individual Yang Mempengaruhi Minat Migrasi Tenaga Kerja Wanita Kabupaten Pati Jawa Tengah Ke Malaysia. (Studi Kasus: Kecamatan Sukolilo Kecamatan Gabus Dan Kecamatan Tayu). Penelitian yang dilakukan oleh Listyarini ini yaitu pengambilan keputusan yang dilakukan diri sendiri untuk melakukan migrasi ke luar negeri.

Penduduk yang ingin melakukan migrasi berarti mempunyai pemikiran yang positif. Meskipun sebenarnya lebih baik mengembangkan potensi yang ada di daerah mereka berasal. Tetapi sebagain penduduk justru ingin meninggalkan daerahnya dan mencari daerah tujuan karena daerah tujuan mereka bisa berkembang.

Jadi pengambilan keputusan yang diambil diri sendiri untuk membenahi dirinya didaerah tujuan. Karena di daerah tujuan mereka bisa menemukan jati dirinya sendiri untuk membenahi 
dirinya. Melakukan pergerakan didalam hidupnnya karena individu yang melakukan migrasi ke luar dari daerah tujuan untuk menata perekonomian mereka. Karena mereka ingin lebih baik dari sebelumnya.

\section{Keluarga inti}

Menurut pendapat dari Ravenstain (1880) disebut hukum-hukum migrasi penduduk salah satunya adalah berita dari sanak saudara yang berpindah dari daerah lain merupakan informasi yang sangat penting bagi orang-orang yang ingin bermigrasi. Keluarga inti berperan untuk mengambil keputusan dalam menentukan pilihan untuk bermigrasi. Pengambilan keputusan keluarga inti dilakukan oleh pak Rozak, pak Rozak migrasi ke Malang karena orang tua Pak Rozak sudah lama tinggal di Malang. Dahulu pak Rozak diasuh neneknya. Ketika pak Rozak sudah dewasa pak Rozak berpindah ke Malang. Karena Pak Rozak meneruskan usaha dagang orang tuanya. Hal ini dijelaskan oleh informan:

\section{"Sudah, hampir 25 tahunnan,} mulai anak saya kecil juga. Karena orang tua iku dulunya sudah di Malang. Saya dulu ikut embah di Madura karena ibu sama bapak saya kerja jadi saya ditiptipkan emak dulu” (Rozak, 2017).

Orang tua Pak Hasan sudah lama tinggal di Malang orang tua pak Rozak usaha berjualan ayam di pasar. Sekarang ini yang meneruskan usaha dagang orangtuanya adalah Pak Rozak. Sama halnya keputusan yang dilakukan oleh Pak Hasan beliau mengambil keputusan ke Malang karena keluarga inti dari dahulu keluarga Pak Hasan sudah berada di Malang. Hal ini dijelaskan oleh informan.
Disini rumah orang tua istri saya, saya mulai disini sejak saya kecil karena mbah buyutnya dahulu juga orang migran Madura” (Abdul, Hasan).

Dalam mengambil keputusan keluarga berperan penting jika ada keluarga yang sudah melakukan migrasi terlebih dahulu dan berhasil mereka akan mendukung anggota keluarga untuk melakukan migrasi. Masyarakat migran Madura mengambil keputusan untuk bermigrasi salah satunya adalah keputusan dari sanak saudara. Keluarga yang lebih dahulu melakukan migrasi ke daerah tujuan akan mempengaruhi migrasi pemula yang ingin melakukan migrasi.

Penemuan yang dilakukan Utami (2012) dengan judul Pengambilan Keputusan Bermigrasi Pekerja Migran Perempuan (Kasus Di Desa Jangkaran, Kecamatan Temon Kabupaten Kulon Progo). Karakteristik migran perempuan yaitu umur mempengaruhi pengambilan keputusan bermigrasi khususnya pada saat keberangkatan migran yang pertama ketika umur migran antara di bawah 20 tahun hingga 35 tahun yang pengambilan keputusan bermigrasinya atas inisiatif keluarga dan orangtua, menunjukkan pada umur migran tersebut belum dapat memutuskan sendiri bermigrasi ke luar negeri.

\section{Jarak}

Jarak juga mempengaruhi untuk pengambilan keputusan untuk melakukan migrasi ke suatu daerah. Masyarakat cenderung melakukan migrasi dari daerahnya ke daerah tujuan lebih dekat, agar jika mereka ingin kembali pulang mereka juga tidak jauh.

Dalam penelitian Sudibia (2005) yang berjudul Kecenderungan Pola Dan DampakMigrasi Penduduk Di Provinsi 
Bali Periode 1980-2005. Menonjolnya jumlah migran semasa hidup yang masuk dari Provinsi Jawa Timur ditentukan oleh beberapa faktor, yaitu (1) jarak yang relatif dekat; (2) tersedianya sarana dan prasarana transportasi yang relatif memadai; dan (3) adanya ketimpangan ekonomi. Provinsi Jawa Timur mempunyai jarak yang relatif dekat dengan Provinsi Bali, sehingga secara logis biaya yang dikeluarkan untuk mencapai tempat tujuan relatif lebih murah. Hal ini sesuai pula dengan hukum migrasi yang menyebutkan bahwa jarak memiliki korelasi negatif dengan jumlah orang yang bermigrasi.

Hal ini dijelaskan oleh informan dengan penjelasan :

"Iya mau kemana lagi, kalau semakin jauh, nantik biaya pulangnya mahal. Kalau dari Malang ke Madura naik bis itu sekitar 20.000 ribu 8 tahun yang lalu"'(Khodir, 2017).

Artinya:

"Iya mau kemana lagi kalau semakin jauh nantik biaya pulang mahal. Dahulu dari Malang ke Madura naik bis sekitar Rp 20.000,00 8 tahun yang lalu” (Khodir, 2017).

Jarak antara Madura dengan Malang yang dekat membuat masyarakat yang ada di Madura tertarik untuk melakuan migrasi ke Kota Malang. Alasan mereka datang ke Malang karena jaraknya relatif dekat. Jika jaraknya dekat biaya yang dikeluarkan tidak terlalu banyak pengeluaran yang dikeluarkan. Di samping itu berita dari sanak saudara yang jika ada keperluan mendadak lansung pulang karena jaraknya tidak terlalu jauh. Jarak yang mereka ambil juga penting jika mereka gagal dalam migrasi mereka tidak membutuhkan materi yang banyak untuk kembali ke kampung daerah asal mereka.

\section{KESIMPULAN}

Sejarah migran bisa sampai di Buring karena di Madura lahannya panas dan kurang subur sehingga tidak bisa dimanfaatkan untuk bercocok tanam. Masyarakat migran Madura melakukan migrasi selain kondisi daerahnya yang kurang subur mereka mencari pekerjaan di Malang. Ada 6 faktor pendorong yang menyebabkan Madura bermigrasi ke Kota Malang yaitu: kondisi lingkungan yang kurang baik, kondisi ekonomi, pendidikan rendah, sarana dan prasarana pendidikan yang kurang memadai, tidak cocok dengan budaya daerah asal, lapangan pekerjaan terbatas. Terdapat 4 faktor penarik dari daerah tujuan yang menarik masyarakat Madura untuk melakukan migrasi yaitu : mendapat pekerjaan yang lebih baik, faktor sarana kenyamanan, kesempatan membuka lapangan pekerjaan, aktivitas Kota besar.

Dalam pengambilan keputusan yang dilakukan migran ada 3 yaitu keputusan diri sendiri, keputusan orang lain dan keputusan keluarga inti. Menurut hasil wawancara migran bermigasi karena faktor ekonomi, mereka di daerah asal tidak mempunyai pekerjaan. Hasil wawancara di lapangan sebagaian informan hanya tamatan SD. Pengamatan di lapangan sebagian besar pekerjaan migran sebagai pedagang. Berdasarkan hasil wawancara di lapangan migran ada yang sudah menikah dan belum menikah. Sebagaian migran dahulunya belum menikah setelah lama di Buring mereka menikah dan akan menetap. Hasil dari wawancara migran melakukan migrasi untuk mencari pengalaman yang baru. 


\section{DAFTAR RUJUKAN}

Listyarini, Nikmah. 2008. FaktorFaktor Individual Yang Mempengaruhi Minat Migrasi Tenaga Kerja Wanita Kabupaten Pati Jawa Tengah Ke Malaysia (Studi Kasus: Kecamatan Sukolilo Kecamatan Gabus Dan Kecamatan Tayu). (Online), diakses 15 Desember 2016.

Mantra,Ida Bagus. 2012. Demografi Umum. Yogyakarta: Pustaka Pelajar.

Muhadjir. 2012. Metode Penelitian Kualitatif Edisi Revisi. Bandung: Remaja Rosdakarya.

Susilo, Singgih. 2015. Tingkat Pendapatan dan Sebaran Tenaga Kerja Indonesia (TKI) Berdasarkan Negara Tujuan, Studi di Desa Aryojeding Kabupaten Tulungagung. Jurnal Pendidikan Geografi. (Online) Diakses 4 Desember 2016.

Rizal, Muhammad. 2006. Keputusan Migrasi Sirkuler Pekerja Sektor Formal di Kota Medan. Jurnal Siasat Bisnis.

Utami, Rizqika. Pengambilan Keputusan Bermigrasi Pekerja Migran Perempuan (Kasus Di Desa Jangkaran, Kecamatan Temon Kabupaten Kulon Progo). Jurnal Skripsi.(Online) Diakses 4 Desember 2016.

Utami, Rina. 2016. Faktor Faktor Yang Mempengaruhi Pengambilan Keputusan Bermigrasi di Desa Tumpak Pelem Kecamatan Sawo Kabupaten Ponorogo. Skripsi tidak diterbitkan. Malang:
Fakultas Ilmu Sosial Universitas Negeri Malang.

Sudibia, I Ketut. Kecenderungan Pola Dan Dampak Migrasi Penduduk Di Provinsi Bali Periode 19802005. Pusat Penelitian Kependudukan Dan Pengembangan SDM Universitas Udayana (Online) Diakses 24 Oktober 2016. 